\title{
IMPLEMENTASI PROGRAM REHABILITASI SOSIAL RUMAH TIDAK LAYAK HUNI
}

\author{
Antonius Erwandi \\ Fakultas Ilmu Sosial dan Ilmu Politik Universitas Kapuas
}

\begin{abstract}
ABSTRAK: Masalah sosial yang masih dihadapi oleh masyarakat yaitu rumah yang tidak layak huni. Oleh sebab itu, penanganan masalah tersebut diharapkan terus ditingkatkan dengan melibatkan seluruh komponen masyarakat (stakeholder) baik pemerintah pusat maupun daerah, dunia usaha, masyarakat, LSM dan elemen lainnya. Penelitian ini menggunakan metode deskriptif kualitatif, adapun subyek dalam penelitian ini adalah Kepala Dinas Sosial, Tenaga Kerja dan Transmigrasi Kabupaten Melawi, Sekretris Dinas Sosial, Tenaga Kerja dan Transmigrasi Kabupaten Melawi, Staf, Kepala Desa Nyanggai dan Warga Masyarakat Yang Menerima Bantuan. Alat yang digunakan terdiri dari Pedoman Wawancara,Pedoman Observasi dan dokumentasi.Hasil penelitian menunjukkan bahwa implementasi program Rehabilitasi Sosial Rumah Tidak Layak Huni yang dilakukan oleh Dinas Sosial, Tenaga Kerja dan Transmigrasi Kabupaten Melawi sudah dilaksanakan sesuai dengan ketentuan yang berlaku. penelitian tersebut dapat disimpulkan bahwa program rehabilitasi sosial rumah tidak layak huni yang dilakukan oleh Dinas Sosial, Tenaga Kerja dan Transmigrasi Kabupaten Melawi yang sudah berjalan dengan baik, sehingga disarankan agar kegiatan dapat dilakukan secara berkesinambungan.
\end{abstract}

Kata Kunci: Implementasi Program, Rehabilitasi Sosial

Dalam Undang-Undang Dasar 1945, pasal 34 menyatakan bahwa fakir miskin dan anak-anak terlantar dipelihara oleh Negara. Hal ini menunjukan bahwa negara sangat memperhatikan setiap warga negara yang berkekurangan. Banyak cara yang ditempuh oleh Negara untuk menanggulangi masalah kemiskinan, salah satunya adalah program rehabilitasi sosial bagi masyarakat tidak mampu atau masyarakat miskin. Arah penanggulangan kemiskinan lebih diprioritaskan pada pengembangan kapasitas serta pontensi masyarakat miskin, sehingga mereka dapat terlepas dari kemiskinan secara mandiri dan berkelanjutan. Penanggulanagan kemiskinan tentu bukan monopoli pemerintah dengan berbagai departemen sektoral yang ada, tetapi merupakan permasalahan multidimensi yang menjadi tanggung jawab seluruh pihak yang terkait. Kemiskinan merupakan permasalahan bangsa yang mendesak dan memerlukan langkah-langkah penanganan dan pendekatan yang sistematik, terpadu dan menyeluruh dalam rangka mengurangi beban dan memenuhi hak-hak dasar warga negara secara layak untuk menempuh dan mengembangkan hidup yang bermartabat.

Sebagaimana yang diamanatkan dalam Peraturan Presiden Republik Indonesia Nomor 13 Tahun 2009 Tentang Koordinasi Penaggulangan Kemiskinan, bahwa penanggulangan kemiskinan adalah kebijakan dan program pemerintah. Pemerintah dalam hal ini Pemerintah Daerah melakukannya secara sistematis, terencana dan bersinergi dengan dunia usaha dan masyarakat untuk mengurangi jumlah penduduk miskin dalam rangka meningkatkan derajat kesejahteraan rakyat.
Dalam Pasal 4 Peraturan Presiden Republik Indonesia Nomor 13 Tahun 2009 dijelaskan bahwa program penanggulangan kemiskinan dikelompokan menjadi 3 (tiga) kelompok program, Kelompok penanggulangan kemiskinan berbasis bantuan dan perlindungan sosial yang terdiri atas programprogram yang bertujuan untuk melakukan pemenuhan hak dasar, pengurangan beban hidup, serta perbaikan kualitas hidup masyarakat miskin. Kelompok program penanggulangan kemiskinan berbasis pemberdayaan masyarakat yang terdiri atas program-program yang bertujuan untuk mengembangkan potensi dan memperkuat kapasitas kelompok masyarakat miskin untuk terlibat dalam pembangunan yang didasarkan pada prinsip-prinsip pemberdayaan masyarakat. Kelompok program penganggulangan kemiskinan berbasis pemberdayaan usaha ekonomi mikro dan kecil terdiri atas program-program yang bertujuan untuk memberikan akses dan penguatan ekonomi bagi pelaku usaha berskala mikro dan kecil.

Optimalisasi penanggulangan kemiskinan salah satu aspek yang penting ditata terutama dalam masalah pendanaan yang dilakukan melalui pemenuhan biaya penangulangan kemiskinan dengan melakukan penganggaran biaya khusus penangulangan kemiskinan. Untuk keperluan tersebut pemerintah menerbitkan Peraturan Menteri Keuangan Nomor 168/Pmk.07 Tahun 2009 Tentang Pedoman Pendanaan Urusan Bersama Pusat dan Daerah untuk penanggulangan kemiskinan. Dalam Rencana Pembangunan Jangka Panjang Nasional (RPJPN) Pemerintah telah menempatkan upaya penanggulangan kemiskinan dan pengurangan 
ketimpangan pembangunan antar wilayah sebagai bagian dari prioritas utama pembangunan nasional dalam agenda meningkatkan kesejahteraan masyarakat, terdapat 5 (lima) sasaran yang ingin dicapai dalam agenda tersebut yaitu : Menurunnya jumlah penduduk miskin dan terciptanya lapangan pekerjaan yang mampu mengurangi tingkat pengangguran terbuka. Berkurangnya kesenjangan antar wilayah yang tercermin dari meningkatnya peran pedesaan sebagai basis pertumbuhan ekonomi, meningkatnya pembangunan pada daerahdaerah terbelakang dan tertinggal meningkatnya pengembangan wilayah yang didorong oleh daya saing kawasan dan produk-produk unggulan daerah; serta meningkatnya keseimbangan pertumbuhan pembangunan antar kota-kota metropolitan, besar menengah, dan kecil dengan memperhatikan keserasian pemanfaatan ruang dan penatagunaan tanah. Meningkatnya kualitas manusia yang secara menyeluruh tercermin dari membaiknya angka Indeks Pembangunan Manusia (IPM) serta meningkatnya pemahaman dan pengalaman ajaran-ajaran agama. Membaiknya mutu lingkungan hidup dan pengelolaan sumber daya alam yang mengarah pada peng arus utamaan (mainstreaming) prinsip pembangunan berkelanjutan diseluruh sektor dan bidang pembangunan. Membaiknya infra struktur yang ditunjukkan oleh meningkatnya kuantitas dan kualitas berbagai sarana penunjang pembangunan. Permasalahan Rumah Tidak Layak Huni yang dihuni atau dimiliki oleh kelompok fakir miskin memiliki multidimensional. Untuk memperbaiki Rumah Tidak Layak Huni tersebut, Direktorat Pemberdayaan Fakir Miskin mengalokasikan kegiatan Rehabilitasi Sosial Rumah Tidak Layak Huni (RSTLH) Pemerintah Daerah Kabupaten Melawi, dalam hal ini Dinas Sosial Tenaga kerja Dan Transmigrasi adalah Dinas yang menyelenggarakan Program Rehabilitasi Sosial Tidak Layak Huni bagi masyarakat di Desa Nyanggai Kecamatan Pinoh Selatan. Desa Nyanggai terdiri dari empat Dusun yang memiliki luas wilayah $10.000 \mathrm{Km}^{2}$.

\section{Pengertian Kebijakan}

Suatu kebijakan yang dibuat dalam rangka pemecahan masalah harusnya berorientasi pada pemecahan masalah riil yang ada di masyarakat, karena umumnya kebijakan dibuat selalu berorientasi pada kepentingan publik. Defenisi mengenai kebijakan publik (public policy) sudah banyak diungkapkan para ahli untuk memperjelas makna dari kebijakan. Salah satunya seperti yang diungkapkan oleh David Easton $(1965,212)$ yang dikutip oleh Nugroho (2008:53) mendefenisikan sebagai akibat aktivitas pemerintah (the impact of gevernment activity). Menurut Santoso (1993:4) pandangan mengenai kebijakan publik dapat dibagi ke dalam dua wilayah katagori yaitu (1) pendapat para ahli yang menyamakan kebijakan publik dengan tindakan-tindakan pemerintah, (2) Pendapat para ahli yang memberikan perhatian khusus pada pelaksanaan kebijakan. Pendapat pertama melihat kebijakan publik dalam tiga lingkungan : perumusan kebijakan, pelaksanaan kebijakan dan penilaian. Menurut pandangan ini kebijakan publik secara ringkas dapat dipandang sebagai proses perumusan, implementasi dan evaluasi kebijakan. Sedangkan pandangan kedua melihat kebijakan publik sebagai serangkaian keputusan dan tindakan.

Menurut Winarno (2002:101) Implementasi kebijakan pada sisi yang lain merupakan fenomena yang kompleks yang mungkin dapat dipahami sebagai proses, keluaran (out put) maupun sebagai hasil. Menurut Van Meter dan Van Horn sebagaimana dikutip oleh Agustino (2006: 54) Implementasi kebijakan adalah sebagai tindakantindakan yang dilakukan oleh individu-individu atau pejabat-pejabat atau kelompok-kelompok pemerintah atau swasta yang diarahkan pada tercapainya tujuan-tujuan yang telah digariskan dalam keputusan kebijaksanaan". Sebagaimana yang diungkapkan oleh Chareles O Jones (dalam Dunn,1981:44) "a policy prioblem is an underealized value, need or oppurtunity which, however identified, maybe attained through public actions". Suatu kebijakan dapat terealisasi apabila kebijakan itu dibutuhkan masyarakat, artinya kebijakan yang dibuat oleh pemerintah harus mencerminkan kehendak atau kepentingan publik karena kebijakan muncul didahului oleh tindakan-tindakan publik". Dari pendapat tersebut dapat dimaknai bahwa keberhasilan suatu kebijakan yang dibuat oleh pemerintah adalah apabila kebijakan yang dibuat memperhatikan kepentingan masyarakat secara menyeluruh, bukan untuk kepentingan individu atau kelompok-kelompok tertentu.

Menurut Tachjan (2008:35) “Target group (kelompok sasaran) yaitu sekelompok orang atau organisasi dalam masyarakat yang akan menerima barang dan jasa atau yang akan dipengaruhi perilakunya oleh kebijakan. Mereka diharapkan dapat menerima dan menyesuaikan diri terhadap pola-pola interaksi yang ditentukan oleh kebijakan." Beberapa pendapat tentang implementasi kebijakan tersebut di atas menunjukan bahwa suatu kebijakan yang dibuat selalu diharapkan dapat dilaksanakan dengan baik dalam rangka mencapai tujuan yang dikehendaki. Salah satu kebijakan tersebut adalah dalam bentuk program rehabilitasi sosial rumah tidak layak huni yang diprogramkan oleh Kementrian Sosial Republik Indonesia, dalam hal ini dilaksanakan oleh Pemerintah Daerah Kabupaten Melawi melalui Dinas Sosial Tenaga Kerja dan Transmigrasi, yang dilaksanakan di Desa Nyanggai Kecamatan Pinoh Selatan. 
Proses implementasi sebuah kebijakan akan berhasil atau gagal dalam mencapai tujuan telah ditentukan oleh jenis kegiatan dari program yang akan dilaksanakan. Dalam hal kegagalan kebijakan Hogwood dan Gun (Wahab, 1991:47) telah membagi makna kegagalan kebijakan (policy failure) ke dalam dua katagori : tidak terimplementasi (non implementation) dan implementasi yang tidak berhasil (unsuccesful) penyebab kedua hal tersebut menurut Wahab (1991:48) yaitu : Langkanya sumber-sumber, kebijakan yang dirumuskan secara sembrono, dan perlawanan dari kelompok sasaran boleh jadi merupakan penyebab dari semua itu. Tidak terimplementasikan mengandung arti bahwa suatu kebijakan tidak terlaksanakan sesuai dengan rencana, mungkin karena pihak-pihak yang terlibat dalam pelaksanaannya tidak mau bekerja sama ataumereka bekerja tidak secara efisien, bekerja setengah hati atau mungkin permasalahan yang digarap diluar jangkauan kekuasaannya, sehingga betapapun gigihnya usaha mereka tanggulangi. Akibatnya implementasi yang efektif sukar untuk dipenuhi. Proses pelaksanaan program rehabilitasi sosial rumah tidak layak huni dilakukan dengan landasan hukum yang kuat dan termuat dalam Pedoman Rehabilitasi Sosial Rumah Tidak Layak Huni dan Sarana Prasarana Lingkungan. Adapun Landasan Hukum tersebut terdiri dari :

1. Undang - Undang Dasar 1945 Pasal 27 (2) Pasal 33, dan pasal 34

2. Undang-Undang Nomor 4 Tahun 1992 tentang Perumahan dan Pemukiman

3. Undang-Undang Nomor 11 Tahun 2009 tentang Kesejahteraan Sosial

4. Peraturan Pemerintah Nomor 42 Tahun 1981 tentang Pelayanan Kesejahteraan Sosial bagi Fakir Miskin

5. Peraturan Presiden Nomor 13 Tahun 2009 tentang Koordinasi Penanggulangan Kemiskinan

6. Keputusan Presiden Nomor 80 Tahun 2003 Tentang Pedoman Pelaksanaan Pengadaan Barang/Jasa

7. Keputusan Menteri Sosial Nomor 84 /HUK/ 1997 Pelaksanaan Bantuan Sosial Bagi Keluarga Fakir Miskin

8. Keputusan Menteri Sosial Nomor 19/HUK/ 1998 tentang Pelayanan Kesejahteraan Sosial bagi Fakir Miskin yang diselenggarakan oleh Masyarakat.

9. Peraturan Menteri Sosial RI Nomor $82 / \mathrm{HUK} /$ 2005 tentang Organisasi dan Tata Kerja Departemen Sosial.

Berdasarkan landasan hukum tersebut pemerintah membuat suatu defenisi atau pengertian mengenai hal-hal sebagai berikut :

1. Miskin adalah orang, keluarga, kelompok atau masyarakat yang tidak mempunyai dana/atau mempunyai sumber mata pencaharian tetapi tidak dapat memenuhi kebutuhan yang layak bagi kemanusiaan.

2. Fakir miskin, adalah orang yang sama sekali tidak mempunyai sumber mata pencaharian dan tidak mempunyai kemampuan memenuhi kebutuhan pokok yang layak bagi kemanusiaan.

3. Rumah tidak layak huni adalah tempat tinggal yang tidak memenuhi syarat kesehatan, keamanan dan sosial

4. Rehabilitasi Sosial Rumah Tidak Layak Huni adalah upaya memperbaiki kondisi rumah baik secara menyeluruh (peremajaan) mau[pun sebagian (pemugaran/renovasi) sehingga tercapai kondisi rumah yang layak sebagai tempat tinggal

5. Sarana prasarana lingkungan adalah fasilitas umum milik masyarakat yang bergerak maupun tidak bergerak yang dibangun untuk mendukung tempat tinggal atau hunian guna meningkatkan kualitas kehidupan.

6. Kelompok RSRTLH adalah kelompok KK penerima bantuan RSRTLH yang terdiri kepala keluarga miskin yang berdekatan tempat tinggal dalam 1 (satu) desa/kelurahan dengan jumlah anggota 5 sampai $10 \mathrm{KK}$, merupakan salah satu pendekatan dalam pelaksanaan rehabilitasi sosial rumah tidak layak huni agar masing-masing anggota dapat saling membantu, berbagai sumber daya sehingga tujuan program pemberdayaan fakir miskin dapat tercapai.

7. TKSK adalah seseorang yang diberi tugas untuk melaksanakan pendampingan dalam penanganan penyandang masalah kesejahteraan sosial di tingkat kecamatan.

8. SP2D adalah kependekan dari Surat Perintah Pencairan dana.

9. SPM-LS adalah kependekan dari Surat Perintah Membayar Langsung.

10. Bantuan Stimulan adalah bantuan dari pemerintah untuk menggugah partisipasi masyarakat,dunia usaha, dan pemerintah daerah dalam RSRTLH dan Sarling. Partisipasi dimaksud dapat diwujudkan dalam bentuk dana, tenaga, barang dan lainnya.

Keberhasilan pelaksanaan rehabilitasi sosial rumah tidak layak huni sebagai sebuah kebijakan yang dijalan suatu organisasi pemerintah dalam hal ini Dinas Sosial Tenaga Kerja dan Transmigrasi Kabupaten Melawi ditentukan oleh pelaksanaa kegiatan yang dilakukan secara sistematis dimulai dari kriteria kepala keluarga penerima bantuan RSRTLH dan dilanjutkan dengan prosedur pengusulan kegiatan. Adapun kriteria dan prosedur Pengusulan kegiatan tersebut ditetapkan dalam Buku Pedoman RS-RTLH dari Kementerian Sosial RI Dirjen Pemberdayaan Sosial Direktorat Pemberdayaan Fakir Miskin. 


\section{Kriteria Kepala Keluarga Penerima Bantuan RS-RTLH :}

Berdasarkan Pedoman pelaksanaan RSRTLH (kementrian Sosial Republik Indonesia tahun 2010) dijelaskan bahwa untuk dapat menerima bantuan perbaikan rumah yang tidak layak harus memenuhi beberapa kriteria, kriteria calon penerima bantuan adalah sebagai berikut : a. Memiliki KTP/identitas diri yang berlaku; $b$. Kepala keluarga /anggota keluarga tidak dapat memenuhi kebutuhan pokok yang layak bagi kemanusiian (memperoleh upah dibawah UMR); c.Kehidupan sehari-hari masih memerlukan bantuan pangan untuk penduduk miskin seperti zakat dan raskin; $d$. Tidak memiliki aset lain apabila dijual tidak cukup untuk membiayai kebutuhan hidup anggota keluarga selama 3 bulan kecuali tanah dan rumah yang ditempati; e. Memiliki rumah di atas tanah milik sendiri yang dibuktikan dengan sertifikat atau akte tanah atau ada surat keterangan kepemilikan dari kelurahan /desa atas status tanah; f. Rumah yang dimiliki dan ditempati adalah rumah tidak layak huni yang tidak memenuhi syarat kesehatan, keamanan dan sosial, dengan kondisi sebagai berikut: 1) Tidak permanen dan / atau rusak; 2) Dinding dan atap dibuat dari bahan yang mudah rusak/lapuk dan sudah rusak, (seperti : papan, ilalang, bamboo yang dianyam/gedeg, dsb) sehingga dapat membahayakan dan mengganggu keselamatan penghuninya; 3) Lantai tanah/semen dalam kondisi rusak;4) Diutamakan rumah tidak memiliki fasilitas kamar mandi, cuci dan kakus.

\section{Prosedur Pengusulan Kegiatan}

Prosedur pengusulan penerima bantuan rehabilitasi sosial rumah tidak layak huni yang telah ditetapkan oleh Kementrian Sosial yang selanjutnya menjadi pedoman bagi Dinas Sosial di daerah adalah sebagai berikut : Dinas Sosial Kabupaten bersama Kepala Desa Nyanggai melakukan pendataan KK calon penerima RTLH; Berdasarkan hasil pendataan tersebut, Dinas Sosial/Instansi Kab/Kota mengajukan permohonan bantuan rehabilitasi sosial rumah tidak layak huni ke Kementerian Sosial dengan rekomendasi Dinas Sosial Provinsi dengan melampirkan data lokasi, data calon penerima (by name by address) dan foto rumah; Kemudian dilakukan Verifikasi administrasi dan verifikasi lapangan dan tahap akhirnya dilakukan alokasi kemudian nama penerima bantuan ditetapkan. Proses pengusulan telah dirancang menggunakan bagan makanisme usulan RS- RTLH sebagai berikut :

\section{Gambar. 2.1. Mekanisme Usulan RS-RTLH}

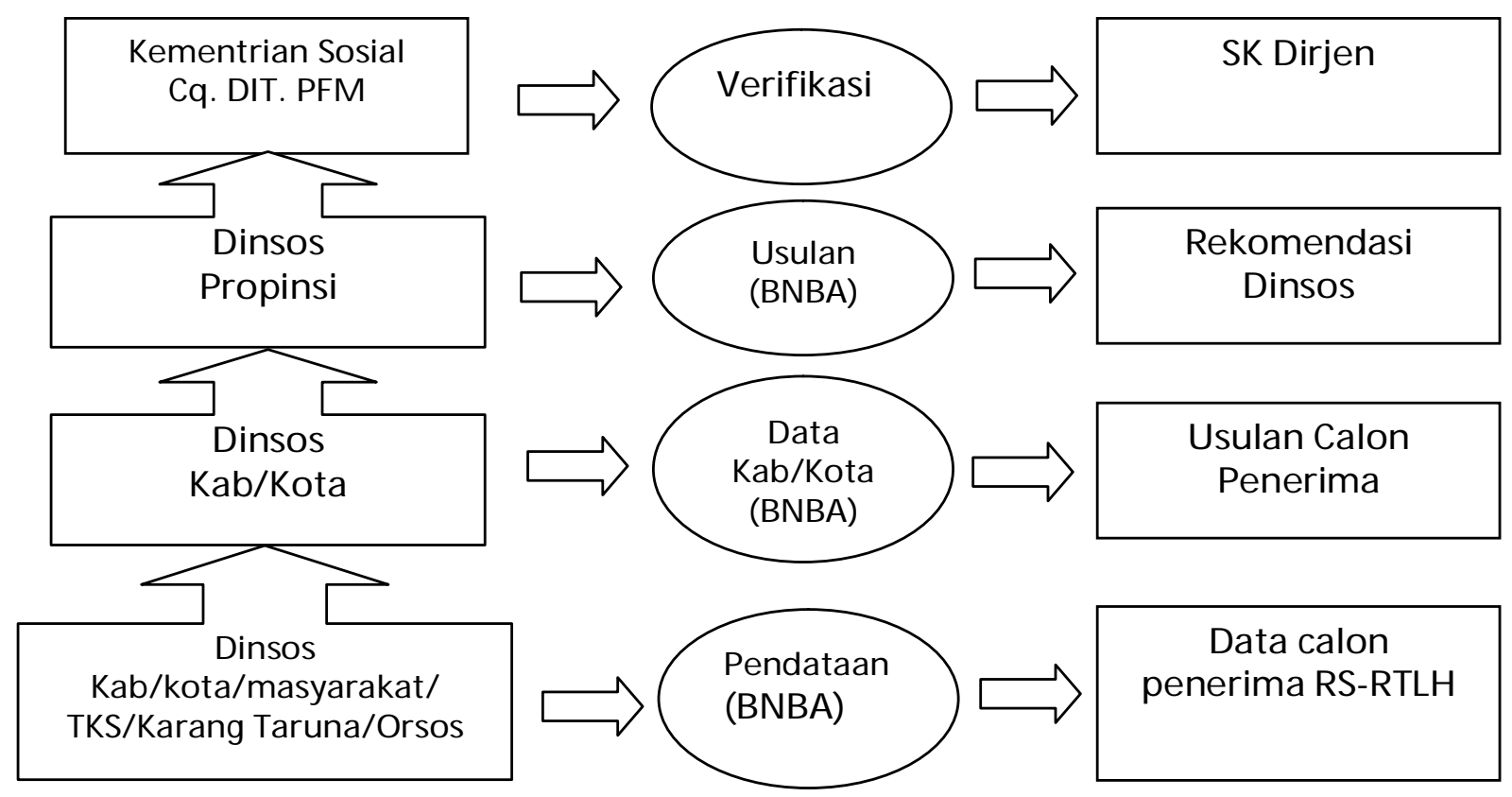

Sumber : Pedoman RS-RTLH Tahun 2010

Melalui mekanisme sebagaimana yang terdapat dalam bagan tersebut, proses pengusulan kepala keluarga yang menerima bantuan adalah secara hirarki bersifat linier yaitu hanya pada lembaga Kementrian Sosial mulai dari tingkat Kabupaten (Dinas Sosial) Hingga pada Kementrian Sosial melalui Dirjen PFM.

\section{HASIL DAN PEMBAHASAN}

Desa Nyanggai Kecamatan Pinoh selatan. Desa Nyanggai terdiri dari 4 (empat) Dusun yang terdiri dari Dusun Nanga Nyanggai dengan KK berjumlah $30 \mathrm{KK}$, Dusun Lamau dengan jumlah KK sebanyak 33 KK, Dusun Tanjung Betikal dengan KK berjumlah $46 \mathrm{KK}$, Dusun Laman 
Rahan dengan KK berjumlah 30 KK. Secara keseluruhan jumlah KK yang ada di Desa Nyanggai adalah 139 KK. Kebijakan rehabilitasi rumah tidak layak huni di Desa Nyanggai merupakan salah satu program pemerintah Kabupaten Melawi yang dilaksanakan atas dasar program yang digulirkan oleh pemerintah pusat melalui Kementerian Sosial. Umumnya masyarakat Desa Nyanggai menyambut baik program Pemerintah Daerah Kabupaten Melawi berupa Rehabilitasi Sosial Rumah Tidak Layak Huni menjadi Rumah Layak Huni, hampir seluruh warga masyarakat yang kurang mampu menghendaki kegiatan ini berlanjut terus, dikarenakan masih banyak rumah yang harus mendapatkan perhatian pemerintah untuk perbaikan menjadi rumah layak huni.

Bahwa masyarakat umumnya menyambut baik program pemerintah ini, dan sangat berharap dilakukan secara berkelanjutan agar semua rumah tidak layak huni yang ada di Desa Nyanggai semua menjadi rumah layak huni. Dalam ketentuan petunjuk pelaksanaan program rehabilitasi rumah tidak layak huni dijelaskan mengenai kelompok penerima bantuan yakni Kepala Keluarga penerima bantuan dengan fasilitasi oleh Dinas Sosial Kab/ Kota membentuk kelompok dengan anggota berjumlah 5 sampai $10 \mathrm{KK}$. Tugas kelompok adalah :Membentuk pengurus kelompok terdiri dari ketua, sekretaris dan bendahara; Membuka rekening di Bank Pemerintah atas nama kelompok dengan specimen ditandatangani oelh ketua dan bendahara; melakukan penilaian bagian rumah yang akan direhabilitasi; Menetapkan toko bangunan yang akan menjamin penyediaan barang; mengusulkan pelaksana yang ahli dalam bidang bangunan(tukang); mengajukan usulan kebutuhan perbaikan rumah beserta dana yang diperlukan maksimal sebesar Rp. 10.000.000,- setiap rumah untuk disetujui oleh Dinas Sosial Kab/Kota.

Umumnya dalam pelaksanaan pada saat pembentukan kelompok tidak terdapat permasalahan yang berarti dikarenakan sebelum dilaksanakan dilakukan sosialisai terlebih dahulu sehingga pada saat dilaksanakan tidak ada perbedaan pemahaman atau pendapat. Hambatan dirasakan sedikit mengganggu kelancaran pelaksanaan adalah tentang penyediaan bahan dari toko sebagaimana ketentuan yang berlaku. Tahap Pelaksanaan bantuan dilakukan dengan Dinas Sosial Kab/Kota melakukan verifikasi proposal RSRTLH sambil melakukan pengambilan data/gambar tentang kesiapan/kelayakan calon daerah dan masyarakat penerima bantuan, Dinas/Instansi Sosial Provinsi, Dinas/Instansi Sosial Kab/Kota, Unsur Masyarakat, pendamping (TKSK) dan dunia usaha bersosialisasi untuk mendapatkan kesamaan dalam pemahaman dan gerak langkah untuk mencapai keberhasilan pelaksana program pembangunan RS-RTLH dengan melakukan penilaian dan menentukan bagian rumah yang akan diperbaiki berdasarkan pada fungsi dan ketersediaan dana dan sumber lainnya sambil membuat rincian jenis/bahan bangunan yang diperlukan serta besarnya biaya dalam pelaksanaan pembelian bahan bangunan dan perbaikan rumah, pelaksanaan pembangunan RSRTLH harus sudah selesai selambat-lambatnya 100 hari setelah dana masuk ke rekening kelompok.

Pelaporan hasil pelaksanaan kegiatan oleh Dinas Sosial Kab/Kota kepada Direktorat Pemberdayaan Fakir Miskin, mencakup : Laporan hasil pelaksanaan kegiatan dengan melampirkan foto rumah dalam kondisi sebelum, proses dan hasil akhir kegiatan dengan disertakan surat pernyataan penyelesaian pekerjaan untuk kelompok, disampaikan selambat-lambatnya 14 hari setelah pekerjaan selesai. Secara umum pelakanaan program rehabilitasi oleh Dinas Sosial bukanlah merupakan proyek-proyek yang harus dilakukan oleh kontraktor akan tetapi berupa bantuan langsung pada masyarakat yang pelaksanaannya juga memerlukan keterlibatan langsung penerima bantuan, sehingga yang diperlukan hanyalah proses pengawasan yang berkenaan dengan waktu dan penyampaian hasil kerja oleh kelompok dan ini akan menjadi proses pelaporan penggunaan dana bantuan oleh Dinas Sosial Kabupaten.

\section{KESIMPULAN DAN SARAN}

Implementasi Program Rehabilitasi Sosial Rumah Tidak Layak Huni di Desa Nyanggai oleh Dinas Sosial, Tenaga Kerja dan Transmigrasi Kabupaten Melawi, telah dilaksanakan sesuai dengan ketentuan yang berlaku dalam petunjuk pelaksanaan program yang ditetapkan oleh Kementerian Sosial, Proses Pelaksanaan Program Rehabilitasi Sosial Rumah Tidak Layak Huni mendapat dukungan Kepala Desa dan seluruh masyarakat. Implementasi Program Rehabilitasi Rumah Tidak Layak Huni lebih efektif jika dilakukan secara berkelanjutan melalui program pemberantasan kemiskinan oleh pemerintah kabupaten mengingat masih banyak masyarakat yang membutuhkan rumah layak huni di daerah perdesaan.

\section{DAFTAR PUSTAKA}

Agustino. Leo. 2006. Politik dan Kebijakan Publik. Bandung: Asosiasi Ilmu Politik Indonesia (AIPI) Bandung Bekerjasama dengan Puslit KP2W Lembaga Penelitian Unpad.

Dunn, William. N. 2000. Pengantar Analisis Kebijakan Publik, Penerjemah Samodra $w$ dkk, Penyunting $M$. Darwin, Edisi Kedua. Yogyakarta: Gajah Mada University Press.

Nugroho,R. 2008. Public Policy Teory Kebijakan-Analisis KebijakanProses Kebijakan Permusan, Implementasi, Evaluasi, Revisi Risk 
Management Dalam Kebijakan Publik Kebijakan Sebagai The Fifth Estate-Metode Penelitian Kebijakan. Jakarta: PT. Elex Media Komputindo Kelompok Gramedia.

Tachjan.H. 2006. Implementasi Kebijkan Publik. Bandung. Puslit KP2W.Lembaga Penelitian Unpad.

Santoso. G. 2005. Metodologi Penelitian. Jakarta : Prestasi Pustaka.

Winarno. B. 1989. Teori Kebijaksanaan Publik. Yogyakarta. UGM : Bina Aksara Universitas Studi Sosial.

Wahab, S.A. 2001. Analisis Kebijakan Dari Formulasi Ke Implementasi Kebijaksanaan Negara. Jakarta : Bumi Aksara.

\section{Perundang-undangan dan Peraturan}

Undang-Undang Dasar 1945.

Pedoman Pelaksanaan Rehabilitasi Sosial Rumah Tidak Layak Huni dan Sarana dan Prasarana Lingkungan.

Peraturan Presiden Republik Indonesia Nomor 13 Tahun 2009 Tentang Koordinasi Penanggulangan Kemiskinan

Peraturan Menteri Keuangan Nomopr 168/Pmk.07 Tahun 2009 Tentang Pedoman Pendanaan Urusan Bersama Pusat dan Daerah untuk penanggulangan kemiskinan. 